\title{
Features of determining controlling effects in functionally-stable systems with recovery of control
}

\author{
Mashkov O. ${ }^{1}$, Chumakevych V. ${ }^{2}$, Sokulsky O. ${ }^{3}$, Chyrun L. ${ }^{2}$ \\ ${ }^{1}$ State Ecological Academy of Postgraduate Education and Management, \\ 35, building 2 Mytropolyt Vasyl Lypkivskyi Str., 03035, Kyiv, Ukraine \\ ${ }^{2}$ Lviv Polytechnic National University, \\ 12 S. Bandera Str., 79013, Lviv, Ukraine \\ ${ }^{3}$ Taras Shevchenko National University of Kyiv, \\ 60 Volodymyrska Str., 01033, Kyiv, Ukraine
}

(Received 29 December 2018; Revised 16 May 2019; Accepted 17 May 2019)

\begin{abstract}
The features of application of the method of inverse problems of dynamics for the recovery control are considered. An expression for the controlling force is obtained as well as simulation for the stage of determining the controlling forces are carried out.

Keywords: functional stability, restoration, the method of inverse problems of dynamics, controlling forces.
\end{abstract}

2000 MSC: $70 \mathrm{G} 70$

UDC: 517.977 .1

DOI: $10.23939 / \mathrm{mmc} 2019.01 .085$

\section{Introduction}

A theory of functional stability arose at the end of the 20th century to improve the control of processes in computing devices of complex aircrafts operating in extreme conditions, which were pricey and potentially hazard during their use. The theory combined various aspects of already well-known theories: reliability, backing, safety, restoration, etc. [1]. The main advantages of this theory are the ability to detect, identify, locate and eliminate the disadvantages of extraordinary situations that occur not only due to the external disturbances but also due to the possible failures within the very system. Subsequently, this theory was extended to cover other multiplex systems and complexes [2-10]. An important component of this theory is the detection of an emergency situation - identification of the state of the objects. The mathematical body allows us to find optimal solutions using known theories: the principle of maximum, dynamic programming, Lyapunov functions, classical variation calculus, analytic constructing of regulators, the method of inverse problems of dynamics, fuzzy sets, etc. A practical application of any method consists in the construction of the control trajectories that implement the extreme values of the functionals. We also note that solving most tasks requires significant computing capacities, e.g., in the analytical construction of regulators for a fifth-order linear system based on the Riccati equations. It is also necessary to take into account the sensitivity of such algorithms to specific values of the parameters of the objects to be controlled $[2-4,9,10]$.

\section{Statement of the problem}

We suggest considering the design of algorithms for the objects to be controlled in the case of emergency situations, in the conditions of uncertainty from the positions of inverse problems of dynamics. The application of such concepts allows constructing effective methods of control, provided the program trajectories of motion are implemented. At the same time, what is essential, a possibility to obtain control in a closed form $U(X(t))$ for both linear and nonlinear systems. 
In the direct formulation, the problem of the synthesis of algorithms of adaptive control systems of a programmatic movement (Fig. 1) is reduced to the definition of the laws of the formation of the control functions $U_{n}^{0}$ (e.g., the movement of control mechanisms of the system, the deviation in the steering box), provided some indicators attainment that indirectly characterize the quality of the control process $J$ (Fig. 1).

In the inverse statement (Fig. 1), the problem of determination of $U_{n}^{0}$ is considered in two stages. In the first stage, the controlling forces $F$ that provide the system with the required movement are determined. These forces can correspond to the real physical forces and momenta that must be applied to the object of the control to provide the optimal programmatic motion $X_{n}^{0}(t)$. In the second stage, the issues of practical implementation of the necessary forces are considered and the control functions $U_{n}^{0}(t)$ are determined.

It is essential, that such a statement of the problem opens a possibility of construction of control systems on the basis on constructive schemes fundamentally different from the usual $[1-4,9,10]$.

The direct task of synthesis

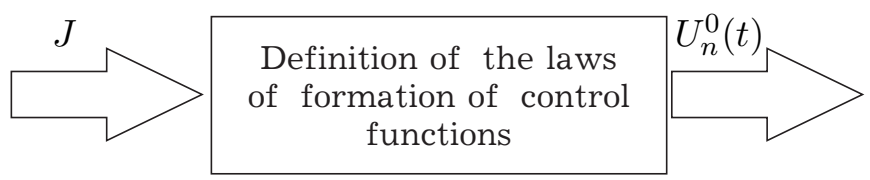

The inverse problem of synthesis

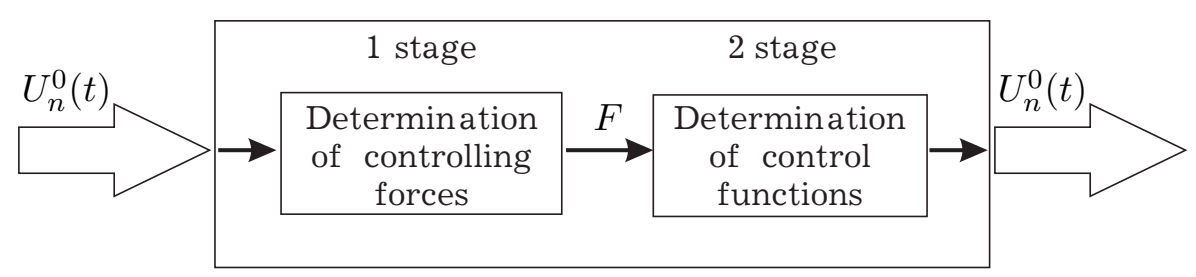

Fig. 1. The block diagram of the statement of the problem of synthesis of control by the method of inverse problems of dynamics.

Such systems are often used as the one-degree-of-freedom system. This limits the possibility of applying the method of solving inverse problems in the cases where it is necessary to control simultaneously all or several phase coordinates of the $n$-th dimensional object.

\section{Description of the mathematical model}

Let us consider the application of the method of inverse problems to a multidimensional object, which is described by the matrix equation in operator form $[1,3,4]$

$$
A(p) X=B(p) U,
$$

where

$$
\begin{gathered}
A(p)=\left\{a_{i j}(p)\right\}, \quad i, j=\overline{1, n}, \\
X^{\mathrm{T}}=\left[X_{1} \ldots X_{n}\right], \\
B(p)=\left\{b_{i j}(p)\right\}, \quad i=\overline{1, n}, \quad j=\overline{1, r}, \\
U^{T}=\left[U_{1} \ldots U_{r}\right] .
\end{gathered}
$$

It is known that this control can be presented in the Cauchy form. 
We construct a control algorithm in which the motion of an object from the point $X(0)$ at the origin of coordinates is carried out along the program trajectory

$$
X_{n}(t)=\left[\begin{array}{c}
C_{11} e^{\lambda_{1} t}+\ldots+C_{1 k} e^{\lambda_{k} t} \\
C_{21} e^{\lambda_{1} t}+\ldots+C_{2 k} e^{\lambda_{k} t} \\
\ldots \ldots \ldots \ldots+\ldots+\ldots+\ldots \\
C_{n 1} e^{\lambda_{1} t}+\ldots+C_{n k} e^{\lambda_{k} t}
\end{array}\right]
$$

or in a matrix form

$$
X_{n}(t)=C e^{\Lambda t}
$$

where

$$
\begin{gathered}
C=\left\{C_{i j}\right\}, \quad i=\overline{1, n}, \quad i=\overline{1, k}, \\
{\left[e^{\Lambda t}\right]^{\mathrm{T}}=\left[e^{\lambda_{1} t} e^{\lambda_{2} t} \ldots e^{\lambda_{k} t}\right],}
\end{gathered}
$$

where $\lambda_{l}(l=\overline{1, k})$ are various real or complex bound numbers satisfying $\operatorname{Re} e^{\lambda_{1}}<0$.

The constant coefficients $C_{i j}, i=\overline{1, n}, i=\overline{1, k}$ are unambiguously defined by the initial values of the phase coordinates and by their $(k-1)$ derivatives

Provided an arbitrary manner in choosing the acceptable values of the parameters $C_{i j}, i=\overline{1, n}$, $i=\overline{1, k}, \lambda_{l}(l=\overline{1, k})$, we obtain a variety of different programmatic movements. The use of arbitrary selection can be used to choose the programmatic movements $X_{n}(t)$ that are the solution of Eq. (1) and satisfy different constraints (e.g., constructive constraints or constraints on traffic safety)

$$
\begin{gathered}
X(0)=\left[\begin{array}{c}
C_{11}+C_{12}+\ldots+C_{1 k} \\
C_{21}+C_{22}+\ldots+C_{2 k} \\
\ldots \ldots \ldots \ldots \ldots \ldots \ldots \\
C_{n 1}+C_{n 2}+\ldots+C_{n k}
\end{array}\right], \\
\dot{X}(0)=\left[\begin{array}{c}
C_{11} \lambda_{1}+C_{12} \lambda_{2}+\ldots+C_{1 k} \lambda_{k} \\
C_{21} \lambda_{1}+C_{22} \lambda_{2}+\ldots+C_{2 k} \lambda_{k} \\
\ldots \ldots \ldots \ldots \ldots \ldots \\
C_{n 1} \lambda_{1}+C_{n 2} \lambda_{2}+\ldots+C_{n k} \lambda_{k}
\end{array}\right] \\
X^{(k-1)}(0)=\left[\begin{array}{c}
C_{11} \lambda_{1}^{k-1}+C_{12} \lambda_{2}^{k-1}+\ldots+C_{1 k} \lambda_{k}^{k-1} \\
C_{21} \lambda_{1}^{k-1}+C_{22} \lambda_{2}^{k-1}+\ldots+C_{2 k} \lambda_{k}^{k-1} \\
\ldots \ldots \ldots \ldots \ldots \ldots \\
C_{n 1} \lambda_{1}^{k-1}+C_{n 2} \lambda_{2}^{k-1}+\ldots . \ldots+C_{n k} \lambda_{k}^{k-1}
\end{array}\right],
\end{gathered}
$$

The controlling force that realizes the trajectory $X_{n}(t)$ is denoted by $f_{n}(t)$. Let us search for such a trajectory in the form

$$
f_{n}(t)=A(p) X_{n}(t)
$$

To obtain a programmatic law governing the change of a controlling force, we substitute the expression (6) into (10),

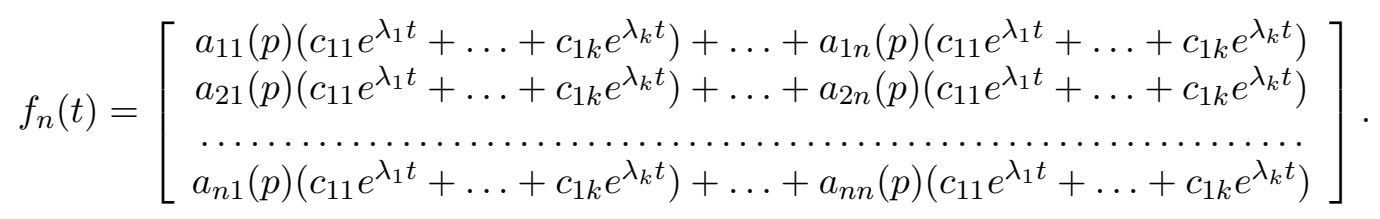

Besides, for $A(p)$ can be written

$$
A(p)=\left\{a_{i j}(p)\right\}=\left\{m_{i j} p^{2}+r_{i j} p+h_{i j}\right\}, \quad i, j=\overline{1, n} .
$$


Substituting the expression (12) into the expression (11), it is possible to obtain the following expression of the controlling force in the matrix form

$$
f_{n}[t]=\left(M C \Lambda_{d}^{2}+R C \Lambda_{d}+H C\right) e^{\lambda t},
$$

where

$$
\begin{gathered}
M=\left\{m_{i j}\right\}, \quad i, j=\overline{1, n} ; \\
C=\left\{c_{i j}\right\}, \quad i=\overline{1, n}, \quad j=\overline{1, k} \\
\Lambda_{d}=\operatorname{diag}\left\{\lambda_{i}\right\}, \quad i=\overline{1, k} \\
R=\left\{r_{i j}\right\}, \quad i, j=\overline{1, n} \\
{\left[e^{\lambda t}\right]^{\mathrm{T}}=\left\{e^{\lambda_{i} t}\right\}, \quad i=\overline{1, k} .}
\end{gathered}
$$

In order the trajectory $X_{n}(t)$ to begin at the point

$$
X_{n}(0)=\left[\begin{array}{ccccc}
X_{10} & \dot{X}_{10} & \ddot{X}_{10} & \ldots & X_{10}^{(k-1)} \\
X_{20} & \dot{X}_{20} & \ddot{X}_{20} & \ldots & X_{20}^{(k-1)} \\
\ldots & \ldots & \ldots & \ldots & \ldots \\
X_{n 0} & \dot{X}_{n 0} & \ddot{X}_{n 0} & \ldots & X_{n 0}^{(k-1)}
\end{array}\right]
$$

the elements of the matrix $C=\left\{c_{i j}\right\}, i=\overline{1, n}, j=\overline{1, k}$ should be determined by solving the $n$ systems of $k$ algebraic equations

$$
\begin{aligned}
& \left\{\begin{array}{c}
C_{11}+C_{12}+\ldots+C_{1 k}=X_{10}, \\
C_{11} \lambda_{1}+C_{12} \lambda_{2}+\ldots+C_{1 k} \lambda_{k}=\dot{X}_{10}, \\
\ldots \ldots \ldots \ldots \ldots \ldots \ldots \ldots \ldots \ldots \ldots \ldots \ldots, \\
C_{11} \lambda_{1}^{(k-1)}+C_{12} \lambda_{2}^{(k-1)}+\ldots+C_{1 k} \lambda_{k}^{(k-1)}=X_{10}^{(k-1)},
\end{array}\right.
\end{aligned}
$$

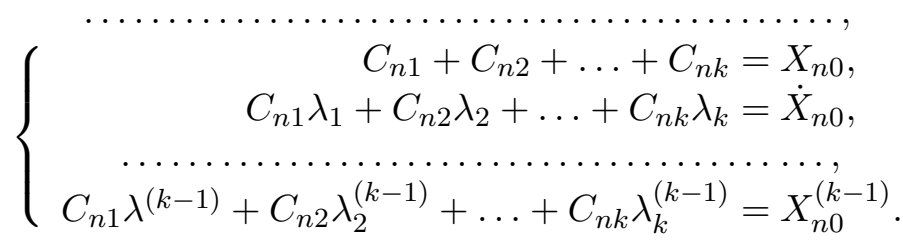

Or in the matrix form

$$
\begin{gathered}
{\left[\begin{array}{cccc}
1 & 1 & \ldots & 1 \\
\lambda_{1} & \lambda_{2} & \ldots & \lambda_{k} \\
\ldots & \ldots & \ldots & \ldots \\
\lambda_{1}^{k-1} & \lambda_{2}^{k-1} & \ldots & \lambda_{k}^{k-1}
\end{array}\right] \times\left[\begin{array}{c}
C_{11} \\
C_{12} \\
\ldots \\
C_{1 k}
\end{array}\right]=\left[\begin{array}{c}
X_{10} \\
\dot{X}_{10} \\
\ldots \\
X_{10}^{(k-1)}
\end{array}\right],} \\
{\left[\begin{array}{cccc}
1 & 1 & \ldots & 1 \\
\lambda_{1} & \lambda_{2} & \ldots & \lambda_{k} \\
\ldots & \ldots & \ldots & \ldots \\
\lambda_{1}^{k-1} & \lambda_{2}^{k-1} & \ldots & \lambda_{k}^{k-1}
\end{array}\right] \times\left[\begin{array}{c}
C_{n 1} \\
C_{n 2} \\
\ldots \\
C_{n k}
\end{array}\right]=\left[\begin{array}{c}
X_{n 0} \\
\dot{X}_{n 0} \\
\ldots \\
X_{n 0}^{(k-1)}
\end{array}\right] .}
\end{gathered}
$$

The solution of these matrix equations has the form:

$$
\left[C_{11} \ldots C_{1 k}\right]^{\mathrm{T}}=\Phi^{-1}\left[X_{10} \dot{X}_{10} \ldots X_{10}^{(k-1)}\right]^{\mathrm{T}}
$$




$$
\left[C_{n 1} \ldots C_{n k}\right]^{\mathrm{T}}=\Phi^{-1}\left[X_{n 0} \dot{X}_{n 0} \ldots X_{n 0}^{(k-1)}\right]^{\mathrm{T}}
$$

where

$$
\Phi=\left[\begin{array}{cccc}
1 & 1 & \ldots & 1 \\
\lambda_{1} & \lambda_{2} & \ldots & \lambda_{k} \\
\ldots & \ldots & \ldots & \ldots \\
\lambda_{1}^{k-1} & \lambda_{2}^{k-1} & \ldots & \lambda_{k}^{k-1}
\end{array}\right]
$$

Note that $\Delta=\|\Phi\|$ is a Vandermonde determinant, which can be written as follows

$$
\prod_{1 \leqslant i \leqslant j \leqslant k}\left(\lambda_{j}-\lambda_{i}\right)
$$

This determinant can be equal to zero and only if $\lambda_{j}=\lambda_{i}, j \neq i$.

As the variables $\lambda_{i}, i=\overline{1, k}$ are chosen to be different, then in our case a Vandermont determinant is nonzero, and, therefore, there exists an invertible matrix $\Phi^{-1}$.

Substituting the expression (16) into the expressions (14), (15), we obtain

$$
C=\left[\begin{array}{cccc}
X_{10} & \dot{X}_{10} & \ldots & X_{10}^{(k-1)} \\
X_{20} & \dot{X}_{20} & \ldots & X_{20}^{(k-1)} \\
\cdots & \ldots & \cdots & \cdots \\
X_{n 0} & \dot{X}_{n 0} & \cdots & X_{n 0}^{(k-1)}
\end{array}\right]=\Phi^{-1}=X(0) \Phi^{-1 \mathrm{~T}}
$$

An expression for a vector of a controlling force can be found by substituting the expression (17) into the expression (13). We have

$$
f_{n}[t]=\left\{M\left(X(0)\left[\Phi^{-1}\right]^{\mathrm{T}}\right) \Lambda_{d}^{2}+R\left(X(0)\left[\Phi^{-1}\right]^{\mathrm{T}}\right) \Lambda_{d}+H\left(X(0)\left[\Phi^{-1}\right]^{\mathrm{T}}\right)\right\} e^{\Lambda t} .
$$

\section{Numerical analysis of the mathematical model}

Evaluate the control algorithm efficiency on the basis of solving the inverse problem of dynamics for stochastic multidimensional automatic system. The investigation will be conducted using MATLAB [11].

Let us consider the system

$$
\dot{X}(t)=\left[\begin{array}{ccc}
0 & 1 & 0 \\
0 & 0 & 1 \\
-0.3 & -3 & -0.1
\end{array}\right] \cdot X(t)+\left[\begin{array}{lll}
2 & 1 & 4 \\
0 & 3 & 2 \\
1 & 0 & 1
\end{array}\right] \cdot U(t)+\left[\begin{array}{l}
1 \\
0 \\
1
\end{array}\right] \cdot \xi(t) .
$$

The equation of the determinant has the form

$$
Z(t)=\left[\begin{array}{lll}
1 & 0 & 0 \\
0 & 1 & 0
\end{array}\right] \cdot X(t)+\eta(t)
$$

The characteristics of random functions have the form

$$
\begin{gathered}
\sigma_{\xi}^{2}=0.01 \\
P_{\eta}=\left[\begin{array}{cc}
0.01 & 0 \\
0 & 0.01
\end{array}\right] .
\end{gathered}
$$

Mathematical Modeling and Computing, Vol.6, No. 1, pp. 85-91 (2019) 
For the perturbed (in mathematical expectation) mode, the parameters of the control law are determined from the condition of approximation of $X(t)$ to the state vector $X(t)$ of the system

$$
\dot{Y}(t)=\left[\begin{array}{ccc}
0 & 1 & 0 \\
0 & 0 & 1 \\
-1 & -3 & -3
\end{array}\right] \cdot Y(t) .
$$

The following functional is adopted as a measure of approximation $X(t) \rightarrow Y(t)$ :

$$
\begin{gathered}
J(c)=\int_{0}^{T}[X(t, c)-Y(t)]^{\mathrm{T}} V[X(t, c)-Y(t)] d t, \\
V=\left[\begin{array}{ccc}
100 & 0 & 0 \\
0 & 10 & 0 \\
0 & 0 & 1
\end{array}\right] .
\end{gathered}
$$

The optimal parameters for the perturbed mode equal

$$
\left\{C_{i j}^{*}\right\}=\left[\begin{array}{cc}
0.386 & 6.308 \\
0.009 & 1.666 \\
-0.197 & -3.672
\end{array}\right]
$$

In Fig. 2, the graphs present the change in mean-square values

$$
\sigma_{i j}=\sqrt{\alpha_{i j}}
$$

of the coordinates state $X_{i}$ for the case when the control law $U(x)=C H X$.

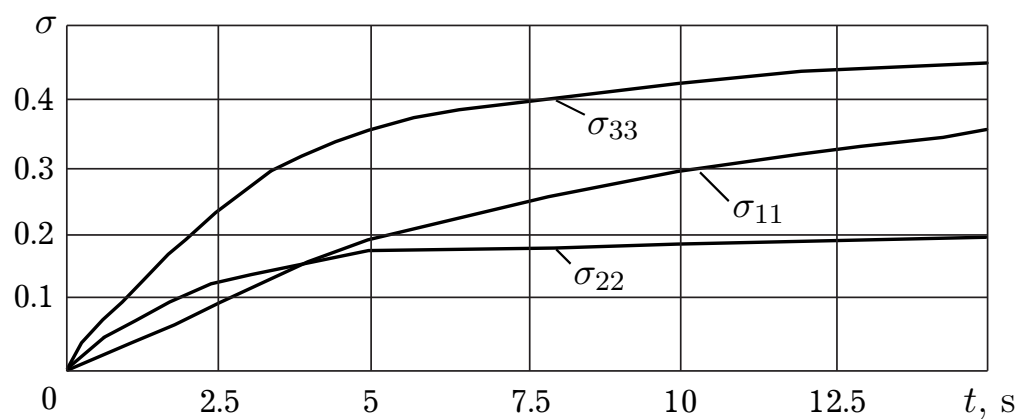

Fig. 2. Graph of changing the mean-square values $\sigma_{i j}=\sqrt{\alpha_{i j}}$ for $C=C^{*}$.

\section{Conclusions}

Analyzing the obtained expression (18), we consider that in order to obtain the desired controlling force it is necessary to do in advance the following: describe the object to be controlled by setting the elements of the matrices $M, R, H$; impose the initial conditions for each control coordinate and their first $(k-1)$ derivatives; set the programmatic trajectory of the movement, by choosing the appropriate elements $\lambda_{i}, i=\overline{1, k}$. By obtaining the expression for the controlling force, the first stage of solving the formulated task ends.

Analyzing the shown in Fig. 2 dependencies, the following conclusions can be drawn:

1. The level of random components in the coordinate state is very high.

2. The parameters $C_{i j}$ found for the perturbed (in mathematical expectation) control mode cannot be considered to be optimal for the unperturbed mode.

The obtained results allow for a functional-stable system to complete the stage of determining the controlling forces; and to continue the investigation and to determine the control functions. 
[1] Improving the efficiency of on-board information management complexes on the basis of detecting and parrying failures in the management process. Report on R \& D No. 09026, KVVIAU (1990), (in Russian).

[2] Azarskov V. N., Kosenko V. R., Kharchevka E. A. Peculiarities of Construction of Functionally-Stable Control Systems of Moving Plants. Electronics and control systems. 24 (2), 52-59 (2010), (in Russian).

[3] Mashkov O. A., Kosenko V.R. Mathematical models and methods of ensuring the functional stability of hierarchical organizational management systems. Aviation and extreme psychology in the context of technological advances. Agrar Media Group. 162-170 (2017), (in Ukrainian).

[4] Mashkov O., Kosenko V. Ensuring of functional stability of difficult dynamic systems as one of urgent scientific tasks of modern theory of automatic control. Informatyka, Automatyka, Pomiary w Gospodarce i Ochronie Środowiska. 3, 39-42 (2015).

[5] Korobchinskyi M. Design of dynamic structural models of information management system of moving objects. Informatyka, Automatyka, Pomiary w Gospodarce i Ochronie Środowiska. 4, 78-80 (2013).

[6] Mashkov V. New approach to system level self-diagnosis. 2011 IEEE 11th International Conference on Computer and Information Technology, Pafos. 579-584. (2011).

[7] MashkovV., Marik V. Diagnosing faulty situations during alliance formation process. Proceedings of IASTED AIA'2003 Conference, Innsbruck. 72-78 (2003).

[8] Korobchinskyi M., BabichevS., Lytvynenko V., Gozhyj A., Voronenko M. A Fuzzy Model for Gene Expression Profiles Reducing Based on the Complex Use of Statistical Criteria and Shannon Entropy. In: Hu Z., Petoukhov S., Dychka I., He M. (eds) Advances in Computer Science for Engineering and Education. ICCSEEA 2018. Advances in Intelligent Systems and Computing, vol. 754, 545-555 (2019).

[9] Shabatura U. V., Paranchuk Ya. S., Chumakevich V. O. Problems of creation of the functional-stable electromechanical complex. Bulletin of Lviv Polytechnic National University, Power and Electromechanical Systems. 707, 114-119 (2011), (in Ukrainian).

[10] Chumakevych V. Singularity of the functional-stable electromechanical complex of agricultural purpose. Bulletin of Lviv National Agrarian University. 20, 115-128 (2016), (in Ukrainian).

[11] Pietruszka W. D. MATLAB und Simulink in der Ingenieurpraxis. Modelbildung, Berechnung und Simulation. B. G. Teubner Verlag (2006), (in German).

\title{
Особливості визначення керуючих впливів у функціонально стійких системах 3 керуванням, яке відновлюється
}

\author{
Машков O. ${ }^{1}$, Чумакевич В. ${ }^{2}$, Сокульський О. ${ }^{3}$, Чірун Л. ${ }^{2}$ \\ ${ }^{1}$ Державна екологічна академія післядипломної освіти та управління, \\ вул. Митрополита Василя Липківсъкого, 35, корпус 2, Київ, 03035, Україна \\ ${ }^{2}$ Національний університет "Львівсъка політехніка", \\ вул. С. Бандери, 12, Львів, 79013, Україна \\ ${ }^{3}$ Київсъкий націоналъний університет ім. Тараса Шевченка, \\ вул. Володимирсъка, 60, Київ, 01033, Украӥна
}

Розглянуто особливості застосування методу зворотних задач динаміки для відновлювального керування. Отримано вираз для керуючої сили та проведено моделювання для етапу визначення керуючих сил.

Ключові слова: функціональна стійкість, відновлююче керування, метод зворотних задач динаміки, керуючі сили.

2000 MSC: $70 \mathrm{G} 70$

Удк: 517.977 .1

Mathematical Modeling and Computing, Vol.6, No. 1, pp. 85-91 (2019) 